\title{
Energy Security: China and the United States and the Divergence in Renewable Energy
}

\section{Brye Butler Steeves* \\ Helton Ricardo Ouriques ${ }^{* *}$}

\begin{abstract}
Historically, great powers have gone to great lengths to guarantee the energy necessary to compete in the international system. Today, as fossil fuel sources diminish and energy demands increase, the most powerful States, specifically China and the United States, are competing for energy resources, including renewable energy sources, while continuing to protect and procure remaining nonrenewable sources around the world. As such, this article's goals are: 1) to offer a brief overview of energy security; 2) to present a brief overview of the energy scenarios of China and the United States; 3 ) to show that China is investing more in renewable energy than the United States due, in part, to the domestic endowment of shale gas of the latter, and the imperative need to diversify the energy sources of the former.
\end{abstract}

Keywords: China; United States; Energy Security; Renewable Energy.

\section{Introduction}

This article examines the efforts being made by China and the United States to maintain and improve their respective energy security, highlighting the incorporation of renewable energy sources. Historically, the world's greatest powers went to great lengths to guarantee the energy necessary to be able to compete in the international system. Today, as fossil fuel sources diminish and demand for energy grows, the most powerful states, including the two aforementioned, are competing for energy resources (including renewable sources), while they continue to protect and acquire the world's remaining fossil fuel sources. Because energy security is necessary for power, states use energy to guarantee national security and grow their global standing. Energy, therefore, has a central role in the structure, consolidation, and survival of states. The strategies, competition and, principally, the motivations of actors to protect and obtain energy resources can be analyzed through the re-

* Federal University of Santa Catarina (UFSC), Florianópolis, SC, Brazil; bryesteeves@gmail.com.

** Federal University of Santa Catarina (UFSC), Florianópolis, SC, Brazil; helton.ricardo@ufsc.br. 
alist paradigm, which explains the interaction between natural resources, power-seeking behavior and interstate conflict.

Thus, when it comes to the theme of energy in the international scene, a big part of the literature adopts a geopolitical, realist theoretical focus. The general assumptions are, in sum: 1) control of and access to natural resources are fundamental for national power; 2) energy resources are rare; 3) competition between states for resources is growing; and, 4) conflicts for resources are probable or inevitable (Dannreuther 2010: 3).

The realist paradigm suggests that interstate competition can result from: national defense strategies that protect energy resources; states' energy supplies and routes, and access to and control of resources. Therefore, countries are motivated by power and always engaged in a fight to increase their capabilities. State behavior is a product of competition. However, this behavior can also be a product of socialization. In other words, states follow norms because it is advantageous for them, or because these norms become internalized. Furthermore, states are seeking security in anarchy because the main threats come from other states (Elman 2010). In other words, state behavior is driven by survival and power, and energy resources are elements of maximizing this power (Cesnakas 2010).

Here we adopt the viewpoint of Michael Klare, an expert in the theme of energy security who, in his books and articles, argues on behalf of state competition for access to and control of energy resources, including sources of renewable energy. In his more recent findings, Klare states, 'like the large resource companies, the world's major powers will also be forced in the coming years to compete more aggressively in the race for what's left' (Klare 2013: 218). However, this aggressive competition can be qualified by cooperative strategies betwen states, also discussed by the authors. Besides this, the incorporation of renewable energy resources can be seen as a 'race for adaptation.' And, in this regard, according to Klare (2013), China has not made a secret of its determination to be a dominant force in the green technology field. In light of the declarations from the memebers of the U.S. government and studies from the PEW Charitable Trusts and the American Energy Innovation Council (AEIC), the authors point out that the United States faces challenges within the renewable energy area.

From the systemic perspective, as put forth by Giovanni Arrighi ${ }^{1}$ and Immanuel Wallerstein, ${ }^{2}$ the current situation of the capitalist world economy is marked by the slow hegemonic decline of the United States. It is in this scenario that the rise of East Asia (and of China, in particular) should be understood as more and more central to the process of capital accumulation. Thus, the incorporation and development of renewable energy sources appear the most relevant for China as an important indicator of its rise and, at the same time, one of the elements that can empirically prove the argument, of these two aforementioned authors, about the United States.

These brief assertions are the theoretical basis of this article that intends to show and explain the difference in intensity between China and the United States in the incorporation of renewable energy. During the 2000-2010 period, China surpassed the United States as the world's largest energy consumer and largest investor in renewable energy. This period also provides statistics from the following data sources: official documents 
from the Chinese and U.S. governments; a comparison of a sample of energy policies from the two countries from the Pew Charitable Trusts foundation and the U.S. Energy Information Administration (EIA); and, an analysis of energy documents of the International Energy Agency (IEA), which is an autonomous organization dedicated to the study of energy. These are the sources of the data presented throughout this article.

The energy policies and energy consumption of China and the United States, as well as their respective energy landscapes, are presented in order to meet the aforementioned primary objective of this article. The first section presents the importance of energy for China, the United States and the international system through the use of information from official organizations and statistical data from 2000 (which are fundamental for the development of the general arguement throughout the text). The text also offers a reflection of the energy security theme and renewable energy, which can be an element to maintain power (the United States) or seek power (China).

\section{The importance of energy for China, the United States and the international system}

Energy is power. From a political, economic and environmental viewpoint, energy security is one of the most important issues faced by all countries in the world. As such, energy has a fundamental role in states' structure, consolidation and survival. Besides this, energy is an important aspect to be able to understand competition in the international system. Considering the competition between states, energy is a crucial factor in the distribution of world power. Therefore, those countries with the most control of energy resources have the biggest power advantage in the international system (Kerr 2012).

States' ability to control energy directly influences their capacity to transform energy resources into wealth and power. The term 'energy secuirty' means that energy sources are sufficient to meet the energy demands of a political community, which include social, economic, and military activity, and that this demand will be met in a reliable, stable manner in the future (Raphael and Stokes 2010). There are various degrees of energy security with differing consequences for countries. In general, when demand is not met, citizens' daily needs, including healthcare, education and transportation, among other quality-oflife issues, can be affected (Kerr 2012). On a much larger scale, countries can be affected militarily and economically.

Today, energy security is an important political issue due to the rapid industrialization of the world, growing populations, high levels of consumption and a significant dependence on non-renewable fossil fuels. Major powers are going to great lengths to establish and guarantee their energy supplies. More and more, they are militarizing their approach to energy security, as evidenced by the United States' involvement in the Iraqi invasion of Kuwait in the 1990s; the 2003 invasion of Iraq and subsequent removal of then dictator Saddam Hussein.

China is still considered a developing country. However, because it is becoming the epicenter of the process of capital accumulation, this country has become the world's lar- 
gest consumer of energy resources and seems to be looking agressively for sources of energy, as evidenced by its bilateral agreements for oil outside the global market. Besides this, China and the United States have been competing for some time for oil in the Caspian Basin, concentrating their respective armed forces and economic resources there, while trying to minimize the other's influence in the area (Raphael and Stokes 2010). Clearly, energy security is inserted into countries' external policies, just as their international actions for its aquisition and protection. Why? First, energy ensures survival by meeting the needs of citizens, and secondly it advances states' pursuit of global power because it supplies armies, facilitates economies, and forges alliances. A country's development and advancement depend on energy (Kerr 2012).

Just as China and the United States have long competed for fossil fuel resources, these two great powers are competing to incorporate renewable energy sources to diversify their respective energy security matrices. This competition between states is intensified by the decline of U.S. ${ }^{3}$ hegemony and the rise of the Chinese economy, as the two compete for a position of global power. Both China and the United States are turning toward the incorporation of renewable energy. Although renewable energy has become a more specific preoccupation of national energy policies for these two countries, it represents a large part of China's national energy consumption and investment, which has a renewable energy investment of more than 30 percent greater than that of the United States (PEW 2014).

It seems China is incorporating renewable energy at a faster pace than the United States, due in large part to its high consumption of native coal, which is the primary energy source of the country's environmental degradation. Additionally, coal is a nonrenewable resource that is estimated to be depleted by mid-century. In terms of energy security, China does not have a choice. It must incorporate alternative sources into its energy matrix. Furthermore, China has thus far not been able to replicate the sucess of the United States' shale gas extraction, known as fracking.

However, China has sufficient renewable natural resources (specifically wind and sun) to potentially meet its future energy demands. Meanwhile, the United States is in the midst of a natural gas boom as a result of its success in shale extraction, which could supply the country with energy for millions of years. While the United States is the world's second largest investor in renewable energy, its investments year after year are dwindling and, at the same time, its extraction of shale gas is growing significantly. It is acknowledged here that there are many factors that contribute to the incorporation of renewable energy, such as economic gains (new jobs associated with the development of renewable resources and their export potential); environmental degradation (pollution and $\mathrm{CO}_{2}$ emissions resulting from the use of fossil fuels); depletion of non-renewable resources (remaining known sources, such as oil, will be unable to meet future energy demands); and political motivations (desires of governments to globally lead clean energy movements), among others.

The effects of energy use by China and the United States are far reaching, impacting the world's markets, economies, environment, public health, and interstate relations. It is also important to mention the relationship between these two countries, the significant implications for global energy, as well as the renewable energy divergence between China 
and the United States. They share common energy challenges, but still do not cooperate significantly in addressing energy issues. The Sino-American relationship, in general, is characterized by inherent differences and distrust of one another, while further challenged by China's economic growth and the relative economic decline of the United States. Thus, there is potential for conflict as seen through energy competition for non-renewable and renewable sources. What's more, the risk of violence is omnipresent when material resources are perceived as necessary for national security because governments will respond to threats with military force (Klare 2000: 300).

In fact, the lack of cooperation in addressing common energy security problems (Zweig and Jianhai 2005) is a form of conflict, although war between the two seems unlikely because of their interdependent relationship, which is globally and historically unprecedented. China and the United States have become interconnected, each counting on the other for its economic health: China is highly dependent on U.S. export markets and U.S. Treasury bond markets for its foreign reserves, and the United States greatly depends on low-cost imports from China, as well as Chinese financing of a significant part of the U.S. budget and deficits (Ho-Fung 2009). However, this interdependence has not, so far, extended much into the realm of energy security, where China and the United States appear quite competitive. Historically, powerful, capitalist states promoted new strategies and structures for the accumulation of capital and power on a global scale that eventually were emulated by peripheral and semi-peripheral actors. These strategies and structures included business related to the acquisition, production, distribution and consumption of energy. In short, states were motivated by power, and energy was used as a channel to enforce the power.

To understand energy's vital role in the international system, it is important to analyze the relationship between energy and state competition as well as actors' behaviour. Considering the competition between states as well as state behaviour, energy is an important factor in the distribution of global power. Due to the fact that energy is necessary for states' self-survival, those states that control energy have a power advantage in the international system (Kerr 2012), which results in competition between states. As energy demand from the world's great powers grows, the supply of non-renewable energy is diminishing. This greatly intensifies competition for the remaining known supplies of fossil fuel sources as well as for the incorporation of alternative fossil fuel sources. The competition for energy sources also seems to be leading to new energy development efforts - as conventional energy prices continue to rise, so does the interest of states for alternative energy sources (Podobnik 2002).

Meanwhile, the world's major powers influence those on the perifery to include renewable energy as they seek energy security. All states appear to be acting in an effort to maintain or increase their overall positions of power. The competition among states affects energy policies through causal relations: 1) material power is needed for states, at a minimum, to able to ensure their own survival and, at a maximum, obtain global power; 2) the accumulation of material resources, including energy resources, is needed for a global position of power in a capitalist economy and especially under a hegemonic transition; and, 3) hegemonic transitions lead to innovation and competition in energy policies. 


\section{Policies and Energy Consumption in China and the United States}

China and the United States face common energy challenges. Both are large energy consumers. Both need energy to maintain stable, growing economies. Both want to minimize environmental degradation. Both seek to diversify their sources of energy for energy security reasons. And today, both these great powers find themselves in an unsustainable situation based on implications that their fossil fuels consumption have for themselves and the rest of the world.

Figure 1 - Total energy production and consumption

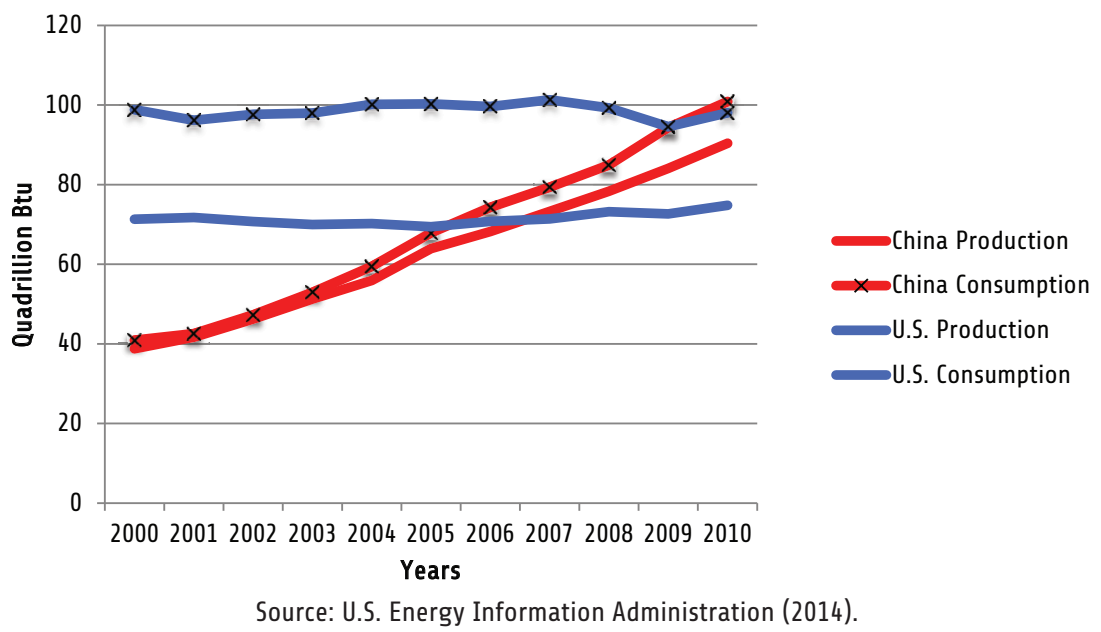

As shown in Figure 1, China surpassed the United States in 2010 as the world's largest energy consumer (U.S. EIA). China's demand for all forms of energy has risen, and is projected to continue to rise, due in large part to the production of export goods and materials for local construction projects. Coal is the dominant source of energy in China (IEA 2007b). Like China, the United States is also almost completely dependent on fossil fuels as its primary energy source. And also like China, the United States is self-sufficient in coal and heavily-dependent on imported oil. It is projected that U.S. energy demand will continue to increase in light of its population and economic growth. The latter is primarily driven by heightened demand in the residential and transport sectors, although all areas show an increased demand (IEA 2007a: 15).

A comparison between the two countries shows that both use more oil than they produce. In 2008, U.S. oil consumption fell slightly and remained as such until 2010. In China, oil consumption has increased year after year during this same time period (Figure 2). From 2000 to 2010, the United States produced more natural gas than it consumed, while the supply and consumption of natural gas in China was more or less balanced during this period (Figure 3). For both China and the United States, coal consumption is 
broadly in line with the amount each country produces, but the volume of coal consumption in China far exceeds U.S. coal consumption. In addition, Chinese coal consumption increased year after year during the 2000-2010 period, while U.S. coal consumption remained mostly constant (Figure 4).

Figure 2 - 0il demand and production

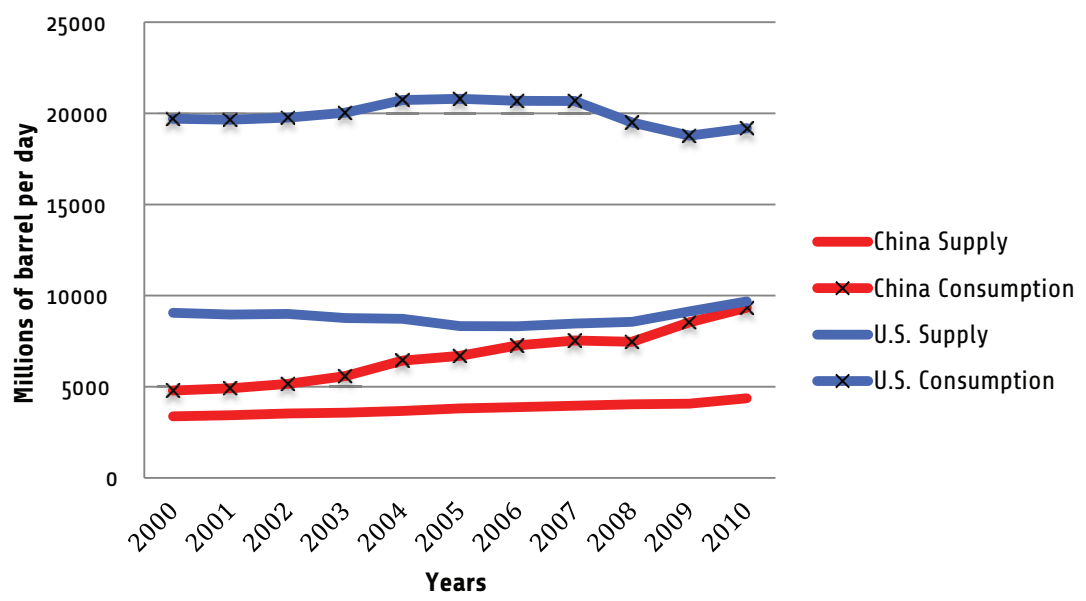

Source: U.S. Energy Information Administration (2014).

Figure 3- Natural gas production and consumption

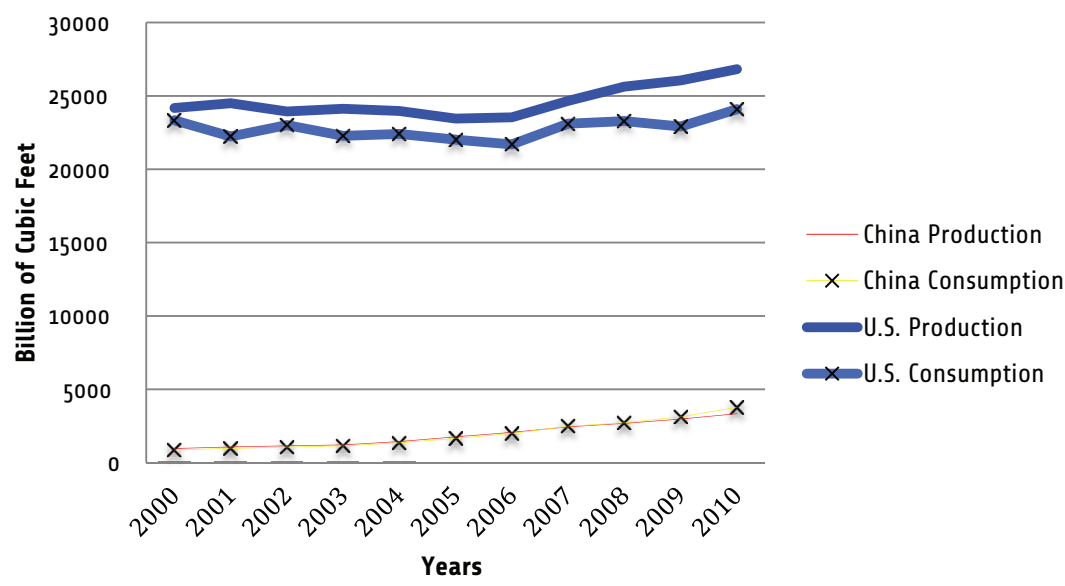

Source: U.S. Energy Information Administration (2014). 
Figure 4 - Coal production and consumption

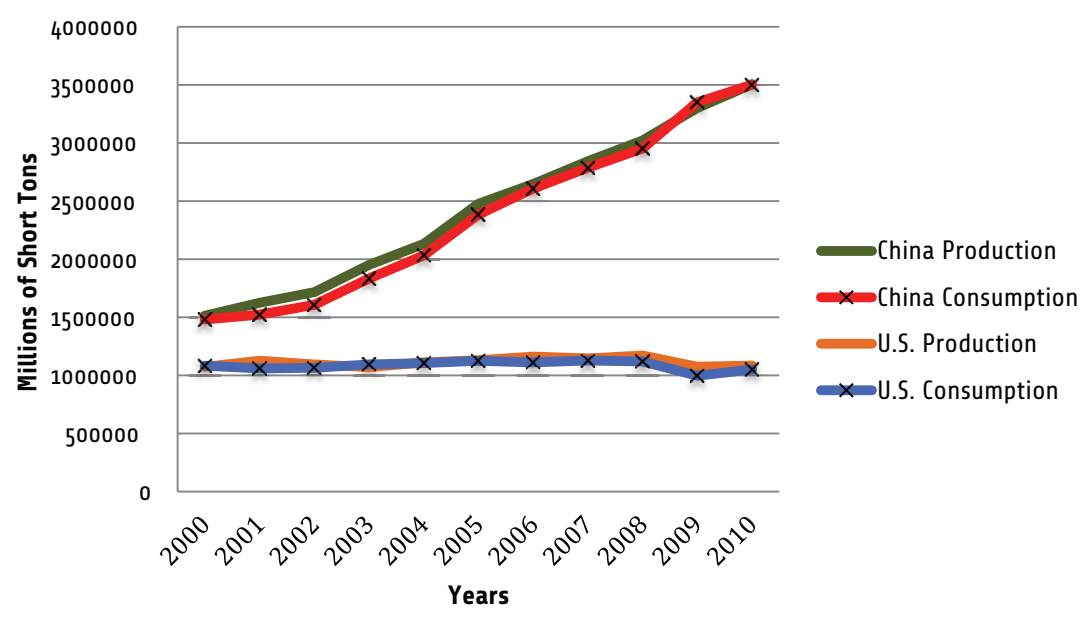

Source: U.S. Energy Information Administration (2014)

Through their respective energy policies and public rhetoric, both countries have identified the need to incorporate renewable energy sources in their energy matrix, driven by economic, environmental, political, and cultural factors (Gallagher 2013). In addition, although less than 10 percent of energy consumption in both countries is derived from renewable sources (U.S. EIA), the two powers seem to be competing to lead the world in the development and use of renewable energy. But, China has a wide lead in the race for clean energy (PEW 2014: 4). Since the middle of this decade, China has gone from being a relatively small player in renewable energy to becoming the 'clean energy superpower of the world' (PEW 2014), both in investment and use. Holding the top spot for several years, China invested 54.2 billion dollars in renewable energy and in 2013 had 191 giga watts of renewable energy capacity. In a distant second place, the United States invested 36.7 billion dollars and in 2013 had 138.2 giga watts of renewable energy capacity. In other words, China has invested 38.5 percent more than the United States and claimed a renewable energy capacity 32.1 percent higher than the United States (PEW 2014: 37, 50).

As stated by PEW (2014: 13-14), 'China's efforts to reduce poverty and increase access to energy, keep up with rapid economic development, and combat severe air pollution in its major cities have driven its rapid rise to the front of the world's clean energy. During the past five years, China's investment in renewable energy grew at a compound annual growth rate of 18 percent. This level of investment has fuelled the adoption of renewable energy, leading to record developments in the implementation of wind farms, solar energy and small capacity hydroelectric power plants. Thus, 'with ample production capacity in the solar and wind sectors, growing domestic markets and unparalleled national targets for renewable energy, China is prepared to lead the world's clean energy market for many years' (PEW 2014: 13, 14). 
At the same time, the United States' incorporation of renewable energy has stagnated, falling nine percent in 2013, likely due to, at least in part, the near-compliance of state renewable energy portfolios and a lack of development of a national energy policy. Analysts indicate that the U.S. renewable energy market has long-term resilience, (PEW 2014: 15), although others worry that the use of renewable energy is threatened by the country's expansion of shale gas (Harvey 2012).

The competitive efforts of China and the United States for energy security also have implications for their respective technological advances and related economic gains. For example, in China the 'efforts to dominate renewable energy technologies' have made it the largest producer of wind turbines and solar panels in just a few years (Bradsher 2010), while at the same time have increased the energy, economic, and environmental risks for its American competitor. In his 2010 State of the Union speech, President Barack Obama said, “... the United States was falling behind other countries, especially China, on energy" (Bradsher 2010) and he also declared that the United States must "win the future" through the renewable energy race (Murray et al. 2011).

Why is the United States falling behind China in its investment and incorporation of renewable energy sources? It seems that the differences in the allocation of natural resources of the two countries, both fossil fuels and renewable sources, could be driving the pace of each country's movement toward clean energy. It is recognized that many factors contribute to the divergence between China and the United States, including political, economic, and cultural factors, although this analysis focuses mainly on the allocation of natural resources and domestic consumption.

\section{China's energy landscape}

China is the world's largest energy consumer, second largest economy and most populous country with 1.3 billion people. China's economy has experienced unprecedented growth during recent decades to become a global economic superpower. At the same time, it holds the title of world's biggest polluter. Its era of energy independence and self-sufficient ideology has ended, replaced by its voracious appetite for energy, which is both the cause and consequence of its fast-growing economy. Today, the success of China's economic growth is inseparable from its dependence on global markets of the capitalist world.

Chinese economic growth over the past three decades has been based on energy consumption, which has exceeded its GDP growth since 2002 (Xing and Clark 2010). China soon became dependent on energy imports, and in 2010 surpassed the United States to become the largest energy consumer in the world. Increasingly, China's high energy use is both a cause and an effect of its unprecedented economic growth, particularly in the heavy industry sector. China's demand for all forms of energy is largely due to the production and exportation of goods, and manufacturing materials for construction projects in the domestic market (IEA 2007b: 261).

China's energy matrix has the following characteristics: 
Coal: Coal represents close to 70 percent of the country's total primary energy consumption, although China's coal sources are low quality, dangerous to mine, highly sulfuric and extremely polluting (Cornelius and Story 2007). China's coal reserves are equivalent to about 12.5 percent of the world's total reserves, and at current production levels, should last until mid-century. Because coal is an abundant, low-cost native resource, China depends on it as its primary energy source. However, this dependence is the primary cause of China's energy-related environmental degradation and is cited as the principal factor in high $\mathrm{CO}_{2}$ emissions. The country is investing in technologies in order to use coal in a cleaner manner (Cornelius and Story 2007).

Oil: Crude oil accounts for less than one-quarter of the country's total energy consumption despite its growing dependence on imported oil, placing it among the main issues on its political agenda. A key factor behind this is the rapid expansion of China's auto fleet. Meanwhile, the country's reserves are estimated at less than 15 years. China is the world's fifth largest oil producer, but in 2011 was dependent on imports to meet about 54 percent of its oil demand. Of its oil imports, more than half comes from the Middle East. There are four large state-owned Chinese oil companies; the government regulates the prices for petroleum products (IEA 2012: 6).

Gas: China is a net importer of natural gas; that is to say that although it is a gas producer and exporter, its total imports exceed the volume of gas exported. This power source accounted for only 4 percent of China's total energy consumption in 2011 (U.S. EIA). The country is also exploring shale gas extraction possibilities to reach known sources of gas that it has not yet been able to extract.

Alternative Sources: Hydro, wind, solar and nuclear energy sources form a small percentage of China's energy matrix and are being further developed, but not enough to reduce China's dependence on fossil fuels (IEA 2007b). However, with its natural endowments of renewable resources, China could meet all its domestic energy demand (Gallagher 2013).

'Nowhere is China's global influence greater than in energy markets' (Cornelius and Story 2007: 7). This applies especially to China's unquenchable thirst for crude oil, which has more than doubled since the mid-1990s. Today, the Chinese economy is the world's second largest oil consumer, and with the stagnation in domestic production, its growing import demand is widely seen as a key factor behind the rise in global oil prices. China's role in global energy development affects its policy formation and interstate relations, environmental protection standards, and the energy efficiency of other global players through the goods it produces and exports. Despite the rapid growth of the country's demand from all sectors of energy, China's global emergence has made the world economy become more dependent on oil, via prices, competition for supplies, and safety concerns. To improve the efficiency of vehicles and electrical appliances that China produces and exports, is to improve energy efficiency for the rest of the world (IEA 2007b: 45).

As a rising global power and large energy consumer, China is on a trajectory that could potentially reshape the global energy landscape. This may be especially true in the areas of conservation and efficient use of fossil fuels, as well as the subsequent global in- 
corporation of renewable energy sources through China's own technological advances and emulation by other countries of its clean energy practices. This potential intersection of economic and political rise with the global energy markets is reminiscent of the increased U.S. demand for oil and dependence on imports, which coincided with its growing strategic power during the $20^{\text {th }}$ Century. As China grows economically, it increasingly plays an important role in determining global technical standards and promoting their convergence. China's growing weight in the global economy can contribute to revolutionizing the world's energy system (Cornelius and Story 2007: 15).

\section{The United States' energy landscape}

The United States is currently the world's largest economy, although there are projections of it being topped by the Chinese economy. With a population of almost 314 million, the United States is the second largest consumer of total energy. The United States is almost entirely dependent on fossil fuels for its energy supply, and renewable sources account for only a small portion of its total matrix. Like China, the United States is self-sufficient in coal and heavily dependent on imported oil. Meanwhile, its demand for energy is expected to continue to increase due to population and economic growth. The latter is driven mainly by an increased demand in the residential and transport sectors, although all areas have seen an increase in demand (IEA 2007a: 15).

The U.S. energy matrix includes:

Oil: Most of the United States' energy consumption, about 36 percent, comes from oil. The country is heavily dependent on imported oil, due to increased demand in the residential and transport sectors. The United States is the largest oil importer in the world, followed by China (Gallagher 2013).

Gas: Natural gas accounts for about 25 percent of the country's energy consumption. Energy from shale gas sources in the United States increased by more than 50 percent annually between 2007 and 2012, increasing total U.S. gas production from 5 percent to 39 percent. In light of these shale gas developments, the United States is 'about to become an energy superpower' (Blackwill and O'Sullivan 2014).

Coal: Nearly 20 percent of U.S. energy consumption is met by coal.

Alternative sources: About 8 percent of U.S. energy consumption is powered by nuclear energy and 9 percent by renewable energy, including solar, geothermal, biomass, and hydro sources. The Energy Policy Act of 2005 describes the use of clean energy in the country, especially a strong movement toward nuclear energy (U.S. EIA). The United States also has significant renewable energy sources in a way that has the potential to lead the world in renewable energy despite its natural endowment of fossil fuels. For example, its wind resources could exceed the total of the projected electricity demand for the entire country, and the conditions for solar energy also look promising. Of note is that countries with less favorable conditions for renewable energy, including China and Germany, have approved greater renewable energy policies (Gallagher 2013). 
Like China, the United States is exerting global influence over the future development of energy. The country has served as a global leader in energy research and development, and has advanced energy technologies. The U.S. government is the largest funder in the world of energy research and development, which historically has promoted the advancement of all energy fields, including fossil, nuclear, and renewable fuels. The government partners with private and educational institutions and international organizations to promote its agenda. The objectives of its policies guide the research and development of energy technologies. These investments in research and development are an important policy tool to meet the country's energy goals. The U.S. government is also the world leader in international collaboration on technology and participates in international organizations focused on energy best practices, such as the International Partnership for the Hydrogen Economy. The United States has several research and development strategies that coordinate the investments in research and technology development, including the Climate Change Technology Program, which is an investment program of several billion dollars for the research, development, and implementation of climate-related technologies. Another example, the Advanced Energy Initiative, works to promote energy efficiency technologies and reduce reliance on imports, including investments in cleaner coal plants and alternative and renewable sources (IEA 2007a: 31, 50).

\section{Energy security and renewable Energy}

Non-renewable energy sources provide about 90 percent of the world's commercial energy, while nuclear power and hydropower provide most of the remaining amount (Podobnik 2002: 253). The problem of energy security can be seen simply as supply and demand: energy needs are growing and showing no signs of slowing yet, at the same time, known sources cannot keep up with this pace of growth. Due to the fact that the world's largest energy consumers cannot meet their energy needs through domestic supplies, and the global supply seems unable to meet future demands, we can see a shift towards renewable energy sources. While this pressure can, and will likely be, mitigated by technological advances and the discovery of new sources, the shortage resulting from the current rate of consumption will lead to competition for access and control, which will increase tension between states (Podobnik 2002).

Both China and the United States are in an unsustainable energy situation. Because of their current high energy consumption, both countries are almost completely dependent on fossil fuels, while renewable sources make up only a small portion of the energy supply. Both countries are self-sufficient in coal, largely self-sufficient in natural gas and heavily dependent on imported oil. Meanwhile, energy demand will continue to increase because of population and economic growth. The latter is mainly driven by increased demand in the residential and transport sectors, although all areas have contributed to the increased demand (IEA 2007a: 15).

It is expected that global demand for energy will exceed known sources and most of the major energy consumers in the world will not have a sufficient domestic supply, especially of oil, to meet this future projected demand. Meanwhile, there is considerable 
political pressure to diversify away from coal consumption because it is considered a major source of pollution and a serious danger to public health. However, governments are also under pressure to promote economic growth in which energy plays a key role. This means that energy security is deeply rooted in foreign policy and is an important factor in relations between states. Therefore, the most important powers in the world are increasing their investments in renewable and sustainable alternatives, including solar, wind, and hydropower. Meanwhile, less powerful states seek to imitate the most powerful states in the world. This is evidenced in some developing nations, like Brazil, India and South Africa, which try to emulate the clean energy policies of the European Union.

The high energy consumption of both China and the United States is a threat to global energy security, and therefore one of their most important political challenges seems to be to develop the ability to meet long-term energy needs reliably, safely, economically, and in an environmentally friendly way. Common challenges include pollution and environmental degradation, inefficient and intensive use of energy, and the depletion of non-renewable resources. Both countries are addressing these challenges in a similar way, with political goals aimed at reducing dependence on imports, reducing emissions of greenhouse gases, and increasing energy efficiency. Both China and the United States have implemented the following national energy policies: carbon cap carbon market, renewable energy standard, tax incentives for clean energy efficient standards, feed-in tariffs and green bonds (PEW 2014: 37, 50). Political action to reduce demand, coupled with increased energy efficiency and the development of new sources, particularly renewables, can be an alternative for these two nations.

There is an intersection between energy security, national development and states' policies (Pautasso and Kerr 2008). Most states are challenged by competition for resources, shortages in energy supply, environmental impacts, and the search for energy policy solutions to address these challenges and to promote world order. In general, the objectives of energy policy include ensuring energy supply safety, generating economic growth and facilitating the preservation of the environment.

A comparison of the energy policies and scenarios (energy supply, demand and reserves) of China and the United States suggests that a change in the energy policies of these states is critical in order to meet the world's contemporary energy security needs. While many of the Chinese and U.S. energy policy solutions are similar, the two countries have little in common in terms of collaboration or cooperation. There does seem to be a great opportunity for cooperation between these states in developing and implementing long-term sustainable energy policies. The world would benefit from energy cooperation between China and the United States as well as a potential transition to a predominantly renewable energy system.

The effects of clean energy are far-reaching. Renewable energy sources contribute to energy security by diversifying energy sources, both technologically and geographically. They affect the economy through imports, exports, job creation, global energy prices, public health and environmental degradation mitigation (IEA.org; Gallagher 2013). Both China and the United States have enough of their own renewable sources to meet all of their potential demand for domestic energy. In addition, the United States has such a significant endowment of renewable energy resources that it could lead the world in renewable energy (Gallagher 2013), despite its recent boom in shale gas. 
Fundamental changes in the global energy system occur more easily during the decline of a great power and when the international system is in disarray (Podobnik 2006), as in the current situation of the relative economic decline the United States and the rise of China (Arrighi 2008). The role of the accumulation of resources and state power is evident in hegemonic transition periods, as were the two previous transitions in the $19^{\text {th }}$ and $20^{\text {th }}$ Centuries. Now, China is emerging as a global economic power in the $21^{\text {st }}$ Century. This hegemonic transition prompts competition and innovation around the globe (Podobnik 2002), not just between the powers in transition. Energy security is no exception. Developed countries and developing countries spend billions of dollars annually incorporating renewables into their energy security policies and for the last eight years there has been a growing trend for larger investments by developing countries.

In recent years, China has led the world in investment in renewable energy, followed by the United States. Four developing countries were among the 10 largest investors in renewable energy in 2012: China, India, Brazil and South Africa, four of the five BRICS nations. These nations' billion-dollar investments place them at the level of major powers, like the United States, Germany, Japan, Italy, the U.K. and France. Russia, the remaining BRICS nation, is an exporter of energy that is also incorporating renewable energy into its national policies. Competition for energy resources also seems to be spurring the development of renewable energy as conventional energy prices continue to rise (Podobnik 2002). History shows that a crisis in a dominant source of energy was mitigated by the transition to another energy source, such as the transition from coal to oil in Great Britain during the $19^{\text {th }}$ Century. Podobnik (2006) suggests that the inevitable oil crisis today will, in part, cause a shift towards renewable energy sources.

The last two centuries show two major transitions of power during periods of industrial growth: the shift from charcoal to coal in the mid- $19^{\text {th }}$ Century, and when oil became the dominant world energy source in the mid-20 ${ }^{\text {th }}$ Century. Many countries appeared to be self-sufficient in energy until around 1950, when they began to become increasingly dependent on energy imports, leading to the transition to oil. Due to the fact that the major powers did not have significant oil reserves, energy needs were underpinned by imports. This strategy does not seem tenable for future energy needs and also seems to be prompting new, and in some cases, more, investments in renewable energy options. Perhaps the energy transition of the $21^{\text {st }}$ Century will be defined by a shift from nonrenewable fossil fuels to renewable energy sources.

Hegemonic advancement can be seen during the energy transition periods, including the transitions of 1750-1850 from peat and charcoal to coal, and the 1900-1950 transition from coal to oil. Coal and steam power, in combination with capital and empire, increased ownership and led to an ecological surplus resulting in food, labor, and cheap energy. The cheap coal, and later (after 1945), cheap oil led to increased consumption and a significant expansion of consumer markets. In addition, cheap raw materials, that is, vital goods such as food, raw materials, and energy were instrumental in the creation and maintenance of large waves of accumulation because this ecological surplus reduces production costs and increases the rate of profit (Moore 2013). 
Today, we see close races for fossil fuels (with the global supply becoming increasingly limited in the medium- and long-term), while countries seek to diversify their respective energy matrices to include alternative sources, such as shale gas extraction and renewable energy to meet their energy needs. It seems that the current global energy system is in transition, with its unsustainable reliance on the use of fossil fuels, including their exhaustion, pollutant nature, and increased demand, as well as the intersection of three systemic dynamics identified by Podobnik (2006) as necessary conditions for a shift in global power. They are: 1) geopolitical rivalry, 2) commercial competition and 3) social conflict. Each of these dynamics is evident today, as we see: 1) competition for existing limited fossil fuels in the world, specifically oil, 2) economic competition for energy technologies, such as foreign investment opportunities and the export of renewable energy, and 3) the chaos that is associated with the hegemonic transition.

In sum, China and the United States are competing for resources, striving for market share and fighting against environmental degradation caused by the excessive use of fossil fuels. Now is the time for an energy transition, but whether it will be in the direction of renewable energy is still uncertain. Moreover, it is necessary to monitor in detail whether China, which has so far been unable to replicate the shale gas boom in the United States, will continue to increase its investment in the use of renewable energy sources to help secure its energy security. In other words, it is worth further investigation based on the current divergence of investments in renewable energy by both China and the United States.

\section{Final considerations}

Concerns about the current state of energy security could trigger deep structural changes in the global energy system (Cornelius and Story 2007: 14). Renewable energy offers the long-term promise of sustainability on several fronts for countries around the world (Heiman and Solomon 2004). Currently, the world's energy needs are growing without showing signs of slowing, while at the same time, known sources of non-renewable energy will not be able to sustain this rate of growth. Although the pressure to meet increasing demands can, and probably will, be mitigated by technological advances and the discovery of new sources (Cornelius and Story 2007), renewable sources appear to be a viable solution to contemporary energy challenges for many countries around the world.

As a global power and the world's highest energy consumer, China is on a path to potentially reshape the global energy landscape, especially in the areas of fossil fuels conservation, more efficient energy use, and the subsequent global incorporation of renewable energy sources. This may be possible through China's own technological advances and the other countries' emulation of its clean energy practices. As it grows economically, China will increasingly play an important role in determining overall technical standards and in the promotion of energy convergence. Its growing weight in the global economy could help revolutionize the world's energy system (Cornelius and Story 2007: 15). Energy challenges in China are no different from other countries with the same problem, but the extent and speed at which change is occurring is unique. Like other countries, China's en- 
ergy policy challenges go hand-in-hand with its economic policy objectives. The country needs to maintain its rapid development and economic growth, but in a much less energy-intensive way. This is widely recognized by the Chinese government, but significant changes in energy consumption relative to economic output could mean major changes in its economic structure (IEA 2007b: 271-2).

The role of the United States in renewable energy should not be discounted, even if it is incorporating proportionally less than China in this area. The United States is the global leader in energy research and development and, furthermore, has always progressed energy technologies. The U.S. government is the world's largest contributor to energy research and development, which has historically provided huge advances such as in the energy fields of fossil fuels, nuclear power, and renewable sources. However, the abundance of shale gas and the increasing reliance on this resource may slow the country's move towards greater incorporation of renewable sources in its energy matrix. Despite its renewable energy resources and capacity to meet energy demands with these sources, the United States appears set to continue its reliance on nonrenewable energy sources because of its abundant natural endowment of shale gas.

Pautasso and Kerr (2008) state that the new world order should be structured based on the symbiotic relationship of the rise of China and the United States' reaction to this rise. Such a transition could result in a change in the balance of power in the international system toward China. A major factor in this transition is related to energy security, as we have seen in previous hegemonic transitions. Stronger cooperation between China and the United States is vital to address the common challenges of energy security, including market stability and supply, as well as new advances in renewable energy that benefit energy consumption, boost economies, and mitigate environmental impacts. However, China and the United States seem to have a long way to go to achieve their respective policy goals for energy efficiency and environmental sustainability. Energy-related relations between them seem to be characterized by a mixture of cooperation, coexistence and competition. Renewable energy is often portrayed as a zero-sum game, but there are reasons for cooperation (Zweig and Jianhai 2005; Murray et al. 2011). As stated by Murray et al. (2011: 7 ): 'It is not uncommon for the terminology to frame the impetus for the development of clean technologies as a war, with the implication that one country will win and others will lose...' However, other countries 'can also win by having access to cleaner energy and use energy more efficiently than they would normally, even if the technologies that produce the energy originates in another country' (Murray et al. 2011).

It is important to stress that relations between China and the United States have been characterized by interdependence. These two great powers are both in competition with each other and mutually dependent on each other in, for example, trade and investments. As noted by Morris (2012), the interactions between these two countries are complex and marked by both cooperation and conflict. China is highly dependent on the U.S. consumer market for its exports and the United States, in turn, depends on large volumes of inexpensive goods produced by China as well as Chinese funding for a significant portion of its current account deficits (Arrighi 2008; Ho-Fung 2009). Therefore, it is unlikely that China will directly challenge U.S. energy supply sources - after all, it still depends on 
U.S. investments and the U.S. market. Taking this into consideration, this article aims to show that China is incorporating and investing in more renewable energy resources, quite possibly with the intent of global leadership in this sector, inclusive of its technological innovations, as highlighted by Klare (2013).

In regard to the United States, the race for renewable energy incorporation has already been acknowledged as a challenge by the U.S. government. In 2014, President Barack Obama announced the expansion of the country's cooperation with China on climate change and clean energy (U.S.-China Joint Announcement 2014). Such an announcement can be understood as the United States' reaction to China's prominence in the field of renewable energy, as demonstrated by the data presented in this article. Moreover, as highlighted by Klare (2013), the dynamics of the American political process should also be taken into consideration when considering the country's investments in renewable energy. For example, as in the present situation, a U.S. congress with a Republican majority probably will not authorize more resources and new projects in the renewable energy sector. ${ }^{3}$

Because the issue of energy is crucial for the power-capital-accumulation processes, China's greater use and development of renewable energy, as presented in this article, are indicators that this country, which has led East Asia' as the most dynamic region in the world economy, also seems to be aiming for world leadership in this strategic sector. Maintaining or even expanding the current scenario described in this article, the divergence between China and the United States in the development, control of, and leadership in renewable energy appears to provide empirical evidence of the end of the American hegemony, defended by Wallerstein and Arrighi.

Although it is too premature to make statements about a new hegemony, China, as an emerging global power and the world's largest energy consumer, is able potentially to reshape the global energy landscape, primarily in the efficient use and conservation of fossil fuels, as well as through the incorporation of renewable energy sources into its energy matrix. However, as highlighted by Arrighi (2008: 392), 'inspired by others in the Western way of excessive energy consumption, China's rapid economic growth has not yet created for itself and the world an ecologically sustainable path of development'.

\section{Notes}

1 Details are in Arrighi's works Chaos and Governability in the Modern World System (2001) and Adam Smith in Beijing (2008).

2 Details of the U.S. hegemonic decline can be found in Wallerstein's The End of the World as We Know It (2002) and The Decline of American Power (2004).

3 'Any significant increase in federal expenditures on renewable energy appears to have little chance of winning approval in the House of Representatives, where anti-spendig Republicans dominate. Likewise, despite the various report's recommendations, it seems improbable that Congress will authorize any expansion of the federal bureaucracy to oversee energy projects of this sort. No doubt some venture capitalists and private companies will put their own funds into new energy initiatives, but such investments are almost certainly not going to reach the minimum level that the President's Council of Advisors identified as necessary for continued American leadership in clean energy design. And without adequate investment, the council predicts, America is destined to become a 'technology taker' rather than a 'technology maker', with the implied economic and leadership consequences' (Klare 2013: 233). 


\section{References}

Arrighi, Giovanni. 2008. Adam Smith em Pequim. São Paulo: Boitempo.

Arrighi, Giovanni and Beverly Silver. Caos e governabilidade no moderno sistema mundial. Rio de Janeiro: Contraponto/Editora da UFRJ, 2001.

Blackwill, Robert D. and Meghan L. O’Sullivan. 2014. 'America's Energy Edge: The Geopolitical Consequences of the Shale Revolution.' Foreign Affairs, March/April. At: http://www.foreignaffairs. com/articles/140750/robert-d-blackwill-and-meghan-l-osullivan/americas-energy-edge [Acessed on 22 July 2014]

Bradsher, Keith. 2010. 'China Leading Global Race to Make Clean Energy' The New York Times, January. At www.agriculturedefensecoalition.org [Acessed on 10 April 2014]

Bradsher, Keith. 'Natural Gas Production Falls Short in China.' The New York Times [online]. 21 Aug., 2014 [Acessed on 5 April 2014]

Cesnakas, Giedrius. 2010. 'Energy resources in foreign policy: a theoretical approach.' Journal of Law \& Politics 3 (1): 30-52.

Cornelius, Peter and Jonathan Story. 2007. China and global energy markets. Elsevier Limited on Behalf of Foreign Policy Research Institute.

Dannreuther, Roland. 2010. 'International Relations Theories: Energy, Minerals and Conflict.' Polinares EU Policy on Natural Resources. Polinares Working Paper, n. 8.

Elman, Colin. 2010, 'Energy Security.' In Colins, Alan (ed), Contemporary Security Studies. New York: Oxford University Press: 15-28.

Gallagher, Kelly Sims. 2013. 'Why and how governments support renewable energy'. MIT Press Journals 142 (1): 59-77 [online] [Accessed on 5 April 2014]

Harvey, Fiona. 2012. 'Golden Age of Gas Threatens Renewable Energy, IEA Warns.' The Guardian [online], May. At www.theguardian.com. [Accessed 10 April 2014].

Heiman, Michael K and Barry D Solomon. 2004. 'Power to the People: Electric Utility Restructuring and the Commitment to Renewable Energy' In: Annals of the Association of American Geographers. 94 (1).

Hiscock, Geoff. 2013. 'Global Competition for Energy Resources on Leaders' Agenda', Available at www.chinausfocus.com. [Accessed on 22 July 2014]

Ho-fung, Hung. 2009. ‘America's Head Servant?: The PRC's Dilemma in the Global Crisis', New Left Review v. 60, nov./dec. [online] Available at: newleftreview.org [Accessed on 5 April 2014].

ICF International. 2012. International Policies Impacting Energy Intensive Industries. United Kingdom. Available at: www.gov.uk [Accessed on 10 April 2014].

IEA (International Energy Agency). 2007a. Energy Policies of IEA Countries: The United States 2007 Review. Available at: www.iea.org [Accessed on 22 July 2014].

2007b. World Energy Outlook: China and India Insights. Available at: www.iea.org [Accessed on 22 July 2014].

2012. Oil \& Gas Security: Emergency Response of IEA Countries. People's Republic of China. Available at: www.iea.org [Accessed 5 Abril 2014].

2011. World Energy Outlook. Available at: www.iea.org [Accessed on 22 July 2014]. 
Kerr, Lucas de Oliveira. 2012. Energia Como Recurso de Poder Na Política Internacional: Geopolitica, Estrategia e o Papel do Centro de Decisao Energetica. PhD Thesis, Universidade Federal do Rio Grande do Sul, Brazil. Available at: http://www.lume.ufrgs.br/handle/10183/76222 [Accessed 15 April 2014].

Klare, Michael T. 2013. The Race for What's Left. New York: Picador. 2008. Rising Powers, Shrinking Planet: The New Geopolitics of Energy. New York: Metropolitan Books/Henry Holt.

2004. Blood And Oil: The Dangers And Consequences Of America's Growing Dependency On Imported Petroleum. New York: Metropolitan Books, 2004. . 2001. 'The New Geography of Conflict', Foreign Affairs v. 80, n. 3: 49-61. 2000. 'Resource Competition in the $21^{\text {st }}$ Century', Current History, n. 99.

Moore, Jason. 2011. 'Ecology, Capital and the Nature of Our Times', American Sociological Association. Journal of World-Systems Research 17(1): 107-146. Available at: http://www.jwsr.org/wp-content/uploads/2013/02/Moore-vol17n1.pdf. [Accessed on 15 April 2014].

Morris, Lyle. 2012. 'Incompatible partners: the role of identity and self-image in the Sino-U.S. relationship', Asia Policy (13): 133-165. Available at: http://www.muse.jhu.edu/journals/asp/summary/ v013/13.mooris.html. [Accessed on 5 April 2014].

Murray, Brian et al. 2011. 'The United States, China, and the Competition for Clean Energy' Policy Brief, v. 11, n. 05 July 2011 [online] Available at: www.nicholasinstitute.duke.edu [Acessed on 5 April 2014].

Obama, Barack. 2013. Remarks by the President in the State of the Union Address. 12 Feb. 2013. [online] Available at: www.whitehouse.gov [Accessed on 05 April 2014].

Pautasso, Diego and Lucas Kerr Oliveira. 2008. 'Energy security of China and the reactions of the USA', Contexto Internacional, Rio de Janeiro (30) 2, May/Aug. 2008.

PEW - Charitable Trusts Foundation. The Pew Charitable Trusts. 2014. 'Who's Winning the Clean Energy Race? 2013 Edition. [online] Available at: www.pewenvironment.org [Accessed on 10 April 2014].

Podobnik, Bruce. 2010. 'Building the Clean Energy Movement: Future Possibilities in Historical Perspective'. In: Kolya Abramsky (ed), Sparking a Worldwide Energy Revolution Oakland. CA: AK Press. pp. 72-80.

2002. 'Global Energy Inequalities: Exploring the Long-term Implications', Journal of World-Systems Research (8) 2: 252-274.

. 2006. Global Energy Shifts. Philadelphia: Temple University Press.

Raphael, Sam and Doug Stokes. 2010. 'Energy Security'. In: Alan Collins (ed), Contemporary Security Studies. New York, NY: Oxford University Press.

Stokes, Doug and Sam Raphael. Global Energy Security and American Hegemony. Baltimore: The Johns Hopkins University Press.

'The Top 10 Countries Investing in Clean Energy'. 2010. [online] Available at: http://www.upi.com/News_ Photos/gallery/Top-10-countries-investing-in-clean-energy/3200/ [Accessed on 10 April 2014].

U.S. Energy Infomation Administration. 2014. [online] Available at: www.eia.gov.

U.S.- China Joint Announcement on Climate Change and Clean Energy Cooperation. November 11, 2014. Available at: www.whitehouse.gov/the-press-office/2014/11/11

Wallerstein, Immanuel. 2002. O fim do mundo como o concebemos. São Paulo, Revan. 
2004. O declínio do poder americano. Rio de Janeiro, Contraponto.

World Bank. 'China Overview. [online] Available at: www.worldbank.org [Accessed on 5 April 2014].

Xie, Tao and Benjamin I. Page. 2010. 'Americans and the Rise of China as a World Power', Journal of Contemporary China (19) 65: 479-501.

Xing, Li and Woodrow W Clark. 2010. Energy concern in China's policy-making calculations: from self-reliance, market-dependence to green energy. Aalborg: Institut for Historie, Internationale Studier og Samfundsforhold, Aalborg Universitet.

Zweig, David and Bi Jianhi. 2005. 'China’s Global Hunt for Energy', Foreign Affairs Sept./Oct.

\section{Acknowledgements}

The authors would like to thank the anonymous reviewers for their suggestions and critiques that proved vital to the final version of this article. Also, thank you to Daniel Castelán and Graciela Di Conti Pagliari for reading the text.

\section{About the Authors}

Brye Butler Steeves is a journalist, who has worked as reporter, writer, and editor at newspapers, magazines, trade journals, and online. She is also the author of a children's book. Steeves recently worked as an economics editor for the Federal Reserve, and is now an international affairs writer and editor. Her research interests include renewable energy and interstate competition between China and the United States. Steeves has a bachelor's degree in journalism from Washington State University in the United States and a master's degree in international relations from the Federal University of Santa Catarina (UFSC) in Florianopolis, Brazil.

Helton Ricardo Ouriques is a professor in the Economics and International Relations Department and in the International Relations Graduate Program at the Federal University of Santa Catarina (UFSC) in Florianopolis, Brazil. He is an economist and holds a $\mathrm{PhD}$ in geography. Ouriques is a member of the World-Systems Political Economy Research Group (GPEPSM). He is a professor of economic geography, geopolitics, the evolution of contemporary capitalism, political economy and the development of comparative historical perspective. His recent research interests include: the development processes in the countries of South America and western Asia (China, in particular); the paths of the development of countries on the periphery of capitalism; and the geopolitical issues of natural resources in the 21 st Century.

Received on 28 January 2015, and approved for publication on 25 August 2015.

(cc) BY-NC https://creativecommons.org/licenses/by-nc/4.0/ 